Article

\title{
An Empirical Study on the Efficiency and Influencing Factors of the Photovoltaic Industry in China and an Analysis of Its Influencing Factors
}

\author{
Hao Cai ${ }^{1,2}$, Ling Liang ${ }^{3, *}$, Jing Tang ${ }^{2}$, Qianxian Wang ${ }^{1}$, Lihong Wei ${ }^{1}$ and Jiaping Xie ${ }^{1, *}$ \\ 1 College of Business, Shanghai University of Finance and Economics, Shanghai 200433, China; \\ caihao06@163.com (H.C.); Wangqianxian1121@163.com (Q.W.); lihongweineo@163.com (L.W.) \\ 2 Jiangsu Provincial Research and Development Center of Energy Internet and Large Data Integration \\ Application Engineering Technology, Changzhou Vocational Institute of Engineering, Changzhou 213164, \\ China; tangjing417@126.com \\ 3 Tourism and Event Management School, Institute of Artificial Intelligence and Change Management, \\ Shanghai University of International Business and Economics, Shanghai 201620, China \\ * Correspondence: liang-ling@foxmail.com (L.L.); jiaping@mail.shufe.edu.cn (J.X.)
}

Received: 29 September 2019; Accepted: 21 November 2019; Published: 26 November 2019

\begin{abstract}
The photovoltaic (PV) industry in China is still in the early stage of development and is extremely unbalanced; breakthroughs in key technologies are necessary. To achieve high efficiency and sustainable development, it is important to identify the bottleneck of the whole industry chain through the analysis of overall industrial technical efficiency. Based on the current situation of the PV industry, this study builds the data envelopment analysis (DEA) model to respectively evaluate the efficiency of PV devices and power generation in the PV industrial chain. The Tobit model is used to conduct an empirical analysis of the factors affecting the efficiency of the PV industry. The results show that the industrial efficiency of PV devices is at a medium level and that it is necessary to strengthen regulation and awareness at the industrial scale. However, the PV power generation industry as a whole is at a low efficiency level, especially the inadequate technical level, which has a negative impact on the improvement of industrial efficiency. Finally, countermeasures and suggestions at the enterprise and government level are put forward to improve the efficiency of the PV industry in China.
\end{abstract}

Keywords: renewable energy; PV industry; data envelopment analysis; technical efficiency

\section{Introduction}

At present, strategic emerging industries represented by the clean energy industry have developed rapidly under the influence of policy dividends, but the front ends of these industrial chains are mostly characterized by high energy consumption. The PV industry is one of the typical examples. It is estimated that by 2030,30\% of the world's whole energy structure will be dominated by renewable energy, and PV power generation will account for more than $10 \%$ of the world's total electricity supply [1,2]. As early as 28 March 2012, Greenpeace Environmental Protection Organization released "Research Report on clean production of China's photovoltaic industry". This report indicated that $\mathrm{PV}$ power generation is an excellent low-carbon energy source and that achieving clean production in the PV industry can result in a win-win situation, achieving both environmental protection and cost reduction. According to the statistics of the 21st Century Renewable Energy Policy Network (REN21), the total installed capacity of PV in China reached 130.5 GW in 2017 [3], accounting for $32.46 \%$ of the global PV installed capacity. The new installed capacity is $53.1 \mathrm{GW}$ [3], which is $68.7 \%$ more than the capacity in $2016[4,5]$. The increasing trend of renewable energy application indicates 
huge market potential for PV industry. For instance, China has become the world's largest and fastest growing country in terms of installed PV capacity [6,7]. However, the front end of the photovoltaic industry chain is the manufacturing process of components such as silicon crystal, and energy costs account for nearly $80 \%$ of the total cost. Additionally, this process is a high emission link. With the constantly worsening front-end environmental pollution in the equipment manufacturing industry, the large-scale power generation industry has currently contradicted its initial intention of protecting the environment [8].

At the same time, the uneven development of the industrial chain has intensified [9]. The production scale of the equipment link is much larger than that of the downstream PV power generation [10]. The production overcapacity and prominent power curtailment ultimately leads to low efficiency of the PV industry [11-13]. The high energy consumption and high emissions of manufacturing links in the PV industry chain, as well as the clean and energy-saving features of the consumption chain, indicate that the Chinese government should focus its development on balancing this industrial chain. All enterprises need to exert their efforts at the same time, through vertical cooperation, increase research and development efforts, and ultimately upgrade the structure of the photovoltaic manufacturing industry to reduce energy consumption and pollution. Therefore, in this article, we separately demonstrate the effectiveness and influencing factors of the above two key links.

The earliest research on efficiency measurement was mainly based on the parametric method to analyze in the field of public utilities such as banks and hospitals, before being used for the energy industry. Maudos (1999) [14] applied the income frontier function to investigate the cost and benefit efficiency of the banking industry in the EU 11 countries in the 1993-1996 period. Barbara (2004) [15] utilized the parametric and nonparametric methods to estimate the total factor productivity of the bank and found that the technical efficiency progress was not inconsistent with measurement conclusions. Joaquin (2004) $[16,17]$ applied both the stochastic boundary function model and a DEA model of mixed data to measure the impact of mergers and acquisitions (M\&A) on bank cost efficiency. Olatubi (2000) [18] used the data envelopment analysis (DEA) method to study the performance level of coal-fired power plants in the United States. Kobayashi (2005) [19] used the transcendental logarithmic model and the Divisia index to compare the total factor productivity of the power industry in Japan, the United States, and South Korea from 1971 to 1996. Hirschhausen (2006) [20] applied nonparametric and parametric tests to evaluate the efficiency of German distribution enterprises, using DEA with constant returns to scale (CRS) as the main productivity analysis technique, and using stochastic frontier analysis (SFA) method for verification. Mukherjee (2008) [21] used four DEA models to measure and evaluate the efficiency of six high-energy-consuming industries in the US manufacturing industry. Campisi, Gitto and Morea (2018) [22] evaluated the multiplicity of measures regarding energy efficiency and reduction in fossil fuel consumption using a multi-criteria analysis (multi criteria decision making (MCDM)). Lam and Shiu (2004) [23] used the DEA-Malmquist method to study the efficiency of thermal power plants in different regions of China from 1995 to 2000 . The research indicated that the levels of technical efficiency are relatively high in the economically developed eastern coastal areas and coal-rich areas. Zhang (2011) [24] sampled the data of thermal power generation panels in 30 provinces and cities in China and applied the SFA method to measure the technical efficiency of the power generation industry. It was found that the overall efficiency level of the power generation industry in China was relatively low-only 0.47. Li (2016) [25] used Bootstrap-DEA correction calculation to analyze the overall technical efficiency of renewable energy generation, including solar PV, wind power and biomass power generation. The research results indicated that with the improvement at the industrial scale and technology level, the overall power generation efficiency in the world was increasingly improved. Zhao et al. (2018) [26] conducted a three-stage DEA analysis and evaluation on the efficiency of renewable energy power generation enterprises and found that the efficiency of the non-power generation industry increased year by year, while the efficiency of the power generation industry remained basically unchanged. Zheng et al. (2015) [27] collected and sorted the data from 23 
domestic PV-listed enterprises in China in 2009-2011 and showed that the overall efficiency of the PV industry was at a high level and increased on a yearly basis.

Research on the factors affecting the efficiency of the PV industry has been mainly at the economy, policy, technology, resource, market and industry scale [28]. Campisi, Morea and Farinelli (2015) [29] evaluated the expected cost of a large-sized photovoltaic (PV) system in reaching grid parity in Italy, not considering any government incentives. Branker (2011) [30] designed a model for calculating the levelized cost of electricity (LCOE). According to the study, when high PV technology level and fine financing conditions coexist, a country's $\mathrm{PV}$ power generation industry may become a new growth point for the economy. Therefore, all countries were called upon to attach importance to the development of the PV power generation industry in order to enhance the level of power generation efficiency. Kong and $\mathrm{Wu}$ (2014) [31] used the DEA-Tobit two-step method to select 18 coal-listed enterprises to analyze the factors affecting the performance of coal enterprises. Their research indicated that the level of economic development and the presence of exploitable resources had a positive impact on business performance. Ding et al. (2016) [32] adopted provincial panel data to point out that Gross Domestic Product (GDP) and urbanization rate had a significant positive impact on PV power generation efficiency, where provinces or cities with high levels of economic development were more inclined to increase PV grid-connected power generation. Wei et al. (2010) [33] argued that with the development of the PV industry and the advancement of technology, the cost of installation, modification and maintenance by untrained personnel underwent expansion. The researchers suggested that a major way to improve the PV industry is to enhance the professional skills of practitioners. Bergh (2009) [34] empirically analyzed the PV industry and pointed out that industrial technology innovation was an important area of focus to promote the rapid development of the PV industry. Tanţău (2014) [35] conducted a one-year empirical study in the field of PV in Romania. By matching the technical parameters with the performance ratios in the efficiency framework, it was believed that the improvement of technical parameters could make a significant contribution to the development of energy efficiency. Lam and Shiu (2004) [26] used the Malmquist index to study that the growth of the total factor efficiency index due to technological advancement; Tobit regression was then used, which indicated that capacity utilization was a major factor affecting technical efficiency. Zhang (2014) [36] used the DEA data envelopment method to select 58 representatives of PV-listed enterprises in China and believed that enterprises needed to improve production efficiency and focused on independent research and development (R\&D) capability instead of blindly expanding production scale. Gollop (1983) [37] studied the relationship between US power industry productivity and environmental regulation and found that the government's regulations that limit $\mathrm{SO}_{2}$ emissions brought about an increase in industrial pollution control costs, which inhibited industrial performance. Bai and Song (2009) [38] conducted an empirical analysis on the environmental regulation effects of thermal power industry in 30 provinces and municipalities of China in 2004. The results showed that environmental regulation could promote power generation efficiency. Wu et al. (2018) [39] stated that the impact of environmental constraints on the technical efficiency of the coal power generation industry was not linear and that there was a "U-shaped" relationship between the two sides. Based on the relative efficiency values of nine selected enterprises in China, the United States, Japan, South Korea and Norway in 2007-2014, Chen et al. (2017) [40] argued that there was a significant correlation between industrial policy and efficiency. Wang et al. (2012) [41] used a two-stage procedure DEA-Tobit model to research the impacts of energy efficiency on Beijing, China. The empirical study demonstrated that the optimization of industrial structure contributed to improving energy efficiency, and the government's working emphasis in the future was to improve the energy efficiency of other energy categories.

Based on a previous research paper, we found that an imbalanced industrial chain hinders the sustainable development of the PV industry in China. The DEA method is commonly applied in the research on industrial efficiency measurement, as it can provide relatively objective and reliable evaluation [42]. However, there are still some shortcomings in these studies, especially when applied to the PV industry. At the micro level, the scholars focus on the improvement of PV conversion 
technology and the external effects on PV conversion efficiency, such as weather, dust and other natural environmental factors. At the macro level majority of papers focus on factors such as economy, policy, technology, resources, market and industry scale for empirical analysis. In general, there is little literature on the efficiency of the overall PV industry chain, and existing literature mainly focuses on traditional energy research. Even for the research on the PV industry, the research object is limited to the PV manufacturing industry, and there are few studies covering the application of PV power generation. Based on the current status of the PV industry in China, this paper uses the DEA method to measure the efficiency of the PV device and power generation industry. The Tobit model is used to empirically analyze factors affecting the efficiency of the PV industry, providing reference for the future development of the PV industry in China.

The structure of this paper is as follows. In the second section, we use the DEA method to measure the efficiency of the PV device industry, and in the third section, the Malmquist index calculation is applied for dynamic analysis. The efficiency of the PV power generation industry is analyzed in the following section. The fifth section uses the Tobit model to empirically analyze the factors affecting the efficiency of the PV industry. Finally, we summarize and provide suggestions for the efficient development of the PV industry in China.

\section{Efficiency Measurement of the PV Industry in China}

DEA is a new methodology of interdisciplinary research employed in management science, mathematical economics, and operations research. DEA is applied to evaluate the performance and efficiency of industries, enterprises and organizations, since it has few constraints. Additionally, there is no necessity for establishing a production function model in advance and no need to consider unit conversion of factors [43-47]. DEA is an efficiency evaluation method for multiple decision units with multiple inputs and outputs. For input and output orientation, this paper uses an input-oriented DEA model [48-51]. In this paper, when studying the industrial efficiency of the whole PV industry chain at different links, representative PV-listed enterprises at different links are selected to measure the overall efficiency of the PV device industry.

\subsection{Selection of Samples and Indicators}

Although there are few restrictions on the choice of indicators in the DEA analysis, too limited a number of decision-making units can easily lead to insignificant results [52]. Therefore, selecting input/output indicators is a crucial step in measuring efficiency. To measure the industrial efficiency, it is necessary to clarify the input and output factors [53]. When Li [54], Yu [55] and Imanirad [56] studied industrial efficiency through DEA analysis, they mainly selected input and output indicators from the three perspectives of personnel, finance and material. Similarly, this paper selects the number of employees, fixed assets, and operating costs as three major input indicators, and operating income as an output indicator to measure the efficiency of the PV device industry. The data sources are mainly the Wind Database, Bloomberg New Energy Finance, annual reports of enterprises, and public data collection (please see the Table 1). 
Table 1. The top 25 solar photovoltaic (PV) device enterprises in China. (Source: Wind Database, Bloomberg New Energy Finance, annual reports of enterprises, and public data collection.).

\begin{tabular}{|c|c|c|}
\hline No. & Enterprise & Main Products \\
\hline 1 & Aikang Technology & PV accessories products, PV brackets \\
\hline 2 & Zhongli Group & Components, cells \\
\hline 3 & Daquan New Energy & Polysilicon, silicon wafer \\
\hline 4 & Foster & Solar battery backplane \\
\hline 5 & Hairun PV & Silicon wafer, cell assembly \\
\hline 6 & Jinjing Technology & PV glass \\
\hline 7 & Jing Yuntong & Silicon wafer, PV equipment \\
\hline 8 & Jinko Energy & PV equipment \\
\hline 9 & Jingsheng Electromechanical & Polysilicon \\
\hline 10 & Jinggong Technology & PV equipment \\
\hline 11 & Kstar & Optical inverter, etc. \\
\hline 12 & Lin Yang Energy & PV modules, cell sheets \\
\hline 13 & Longji shares & Polysilicon, cell sheets, components \\
\hline 14 & CSG Holding & Solar glass, components, battery \\
\hline 15 & TBEA & Inverter \\
\hline 16 & Tianlong Photoelectric & Polycrystalline silicon PV equipment \\
\hline 17 & GCL System Integration Technology & Polysilicon, PV modules \\
\hline 18 & Sunshine power & Optical inverter \\
\hline 19 & Yicheng New Energy & Polysilicon, silicon wafer \\
\hline 20 & Yinxing Energy & PV power generation equipment \\
\hline 21 & Yingli Green Energy & Polysilicon, silicon wafer, battery assembly \\
\hline 22 & Yuhui Sunshine & Silicon wafer, battery assembly \\
\hline 23 & Zhengtai Electric & PV equipment \\
\hline 24 & Tianjin Zhong Huan semiconductor & Polysilicon, silicon wafer \\
\hline 25 & Kehua Hengsheng & Transformer \\
\hline
\end{tabular}

The data shows that up to May 2017, there were more than 105,000 related PV enterprises (excluding Hong Kong, Macao and Taiwan), with 39,000 PV enterprises established in the previous year; the number of enterprises had increased by nearly $60 \%$. With regard to regional locations, enterprises were mainly centralized in Jiangsu, Shandong, Hebei, and other provinces. In this paper, based on the ranking of polysilicon, PV support, inverter, battery and module enterprises released in 2017, 25 representative companies in the PV industry in China were selected as samples. To identify the efficiency of the PV device industry more clearly, the operating data of the 25 representative enterprises listed in Shanghai, Shenzhen and American Stock Exchanges were selected to analyze the efficiency of the PV device industry in China.

\subsection{Analysis of DEA Efficiency Measurement Results}

Based on the above-mentioned input and output indicators from the data collected from 25 PV-listed companies in the five years from 2011 to 2017, the research used DEAP v2.1 software and an input-oriented BCC model to measure the industrial efficiency of PV devices [57]. The overall technical efficiency, pure technical efficiency, and scale efficiency were computed and further analyzed by using the DEA method.

1. Overall technical efficiency analysis

The overall technical efficiency reflects the comprehensive capability level of resource allocation, management capability and technical level in the decision-making units in the PV installation industry in China. From the output level, overall technical efficiency refers to the possibility that PV enterprises can increase their operating income under the established management and technical levels.

As shown in Table 2, eight enterprises had high overall technical efficiency in the seven years from 2011 to 2017, with average efficiency values above 0.9. The only inefficient enterprise was Tianlong 
Photoelectric, with an overall technical efficiency value of 0.527 . The efficiency value of the remaining 16 enterprises was at a medium level, which is between 0.734 and 0.897 , indicating that the efficiency of PV installation enterprises in China was at a medium efficiency level.

Table 2. Overall technical efficiency of PV device enterprises in China, 2011-2017. (Source: Own elaboration.)

\begin{tabular}{|c|c|c|c|c|c|c|c|c|}
\hline Enterprise & 2011 & 2012 & 2013 & 2014 & 2015 & 2016 & 2017 & Average \\
\hline CMC Magnetics & 0.794 & 0.766 & 0.715 & 0.85 & 0.832 & 0.772 & 0.793 & 0.789 \\
\hline Jing Yuntong & 0.969 & 0.732 & 0.526 & 0.765 & 0.875 & 1.000 & 0.918 & 0.826 \\
\hline Longji shares & 0.885 & 0.709 & 0.669 & 0.861 & 0.884 & 0.893 & 0.849 & 0.821 \\
\hline Daquan New Energy & 1 & 0.525 & 0.59 & 1 & 1 & 0.948 & 1.000 & 0.866 \\
\hline Jinko Energy & 0.969 & 0.761 & 1 & 1 & 0.987 & 0.837 & 0.800 & 0.908 \\
\hline Zhengtai Electric & 1 & 1 & 1 & 1 & 0.971 & 0.963 & 0.955 & 0.984 \\
\hline Hairun PV & 0.903 & 0.688 & 0.658 & 0.669 & 0.769 & 0.789 & 0.660 & 0.734 \\
\hline Jinjing Technology & 1 & 0.85 & 0.782 & 0.861 & 0.842 & 0.839 & 0.829 & 0.858 \\
\hline Jinggong Technology & 1 & 0.563 & 0.548 & 0.799 & 0.825 & 0.917 & 0.913 & 0.795 \\
\hline Yuhui Sunshine & 0.694 & 0.685 & 0.761 & 0.826 & 0.823 & 0.760 & 0.815 & 0.766 \\
\hline Foster & 1 & 1 & 1 & 1 & 1 & 1.000 & 0.999 & 1.000 \\
\hline Lin Yang Energy & 0.833 & 0.913 & 0.886 & 1 & 1 & 0.889 & 0.905 & 0.918 \\
\hline GCL integration & 0.819 & 0.456 & 0.33 & 1 & 1 & 1.000 & 1.000 & 0.801 \\
\hline Aikang Technology & 0.803 & 0.774 & 0.902 & 0.979 & 0.937 & 0.808 & 0.830 & 0.862 \\
\hline CSG & 0.997 & 0.908 & 0.918 & 0.914 & 0.86 & 0.841 & 0.773 & 0.887 \\
\hline Zhongli Group & 1 & 1 & 1 & 0.909 & 0.88 & 0.833 & 0.902 & 0.932 \\
\hline Kehua Hengsheng & 0.796 & 0.79 & 0.735 & 0.881 & 0.886 & 0.975 & 0.892 & 0.851 \\
\hline TBEA & 0.915 & 0.764 & 0.83 & 0.875 & 0.861 & 0.853 & 0.898 & 0.857 \\
\hline Annual Average & 0.889 & 0.729 & 0.739 & 0.867 & 0.847 & 0.891 & 0.879 & - \\
\hline
\end{tabular}

According to the data, the annual average efficiency of the PV installation industry in China was between 0.729 and 0.891 , indicating that there is still considerable room for improvement. The overall technical efficiency showed a significant downward trend from 2011 to 2012. This was due to the fact that in 2012, PV installations in China, including PV modules and battery cells, suffered from "anti-dumping and anti-subsidy survey" effects [58-62]. Due to the European debt crisis and shrinking demand, since 2011, the United States, the European Union, India and other countries have successively conducted a series of anti-dumping and anti-subsidy probes on Chinese PV products. In 2012, China's total import and export of photovoltaic products was only 28.95 billion US dollars, a decrease of $32 \%$ compared to 2011 [63]. The PV device industry, with its strong export dependence, was severely impacted [64]. The decline in profits led to a sharp reduction in overseas markets, resulting in poor industrial efficiency. On the other hand, it also reflected the lack of domestic market for PV products in China, oversupply, and unbalanced development of the industrial chain. The efficiency of the industry showed an overall upward trend in 2014-2017. The reason was that China had paid increasing attention to the development of the PV industry and had continuously introduced policies to promote its progress while stimulating PV consumption. The installed capacity of PVs increased from 2.12 million $\mathrm{kW}$ in 2011 to 54.8 million $\mathrm{kW}$ in 2017. The rapidly increasing capacity of the domestic PV market promoted the overall technical efficiency of the PV device industry. In general, the efficiency of the PV installation industry in China during this period was at a medium efficiency level, and the PV industry needed to upgrade its management level and technical capabilities.

2. Pure technical efficiency analysis 
In order to further analyze the efficiency of integrated technology and clarify the formation of overall technical efficiency, we further divide the overall technical efficiency into pure technical efficiency and scale efficiency for analysis. Pure technical efficiency refers to the production efficiency affected by factors such as business management and technology. When the pure technical efficiency level is 1 , it indicates that at the current technical level, enterprise resources are effectively utilized.

According to the average value of the pure technical efficiency of the sample enterprises shown in Table 3, the DMUs (Decision Making Units) with a pure technical efficiency of 1 accounted for 16\% of the total samples, while the pure technical efficiency values of other enterprises were mostly at moderate efficiency levels-between 0.789 and 0.997 .

Table 3. Pure technical efficiency of PV installations, 2011-2017. (Source: Own elaboration.)

\begin{tabular}{|c|c|c|c|c|c|c|c|c|}
\hline Enterprise & 2011 & 2012 & 2013 & 2014 & 2015 & 2016 & 2017 & Average \\
\hline $\begin{array}{l}\text { Jingsheng } \\
\text { Electromechanical }\end{array}$ & 1.000 & 1.000 & 1.000 & 1.000 & 1.000 & 1.000 & 1.000 & 1.000 \\
\hline Longji shares & 0.886 & 0.720 & 0.703 & 0.882 & 0.900 & 1.000 & 1.000 & 0.870 \\
\hline Yicheng New Energy & 0.853 & 1.000 & 0.717 & 0.841 & 0.840 & 0.861 & 0.732 & 0.835 \\
\hline Jinko Energy & 1.000 & 0.763 & 1.000 & 1.000 & 1.000 & 1.000 & 1.000 & 0.966 \\
\hline Zhengtai Electric & 1.000 & 1.000 & 1.000 & 1.000 & 1.000 & 1.000 & 1.000 & 1.000 \\
\hline Hairun PV & 1.000 & 0.735 & 0.762 & 0.718 & 0.804 & 0.840 & 0.666 & 0.789 \\
\hline Jinjing Technology & 1.000 & 0.856 & 0.807 & 0.868 & 0.844 & 0.905 & 0.883 & 0.881 \\
\hline Yingli Green Energy & 0.909 & 1.000 & 1.000 & 0.841 & 0.774 & 0.808 & 0.741 & 0.868 \\
\hline Yuhui Sunshine & 0.707 & 0.721 & 0.781 & 0.832 & 0.825 & 0.792 & 1.000 & 0.808 \\
\hline Foster & 1.000 & 1.000 & 1.000 & 1.000 & 1.000 & 1.000 & 1.000 & 1.000 \\
\hline Lin Yang Energy & 0.846 & 0.921 & 0.909 & 1.000 & 1.000 & 0.961 & 0.996 & 0.948 \\
\hline $\begin{array}{c}\text { GCL System Integration } \\
\text { Technology }\end{array}$ & 0.834 & 0.495 & 0.800 & 1.000 & 1.000 & 1.000 & 1.000 & 0.876 \\
\hline Aikang Technology & 0.863 & 0.820 & 1.000 & 0.985 & 0.962 & 0.833 & 0.831 & 0.899 \\
\hline CSG Holding & 1.000 & 0.940 & 0.993 & 0.927 & 0.887 & 0.947 & 0.891 & 0.941 \\
\hline Zhongli Group & 1.000 & 1.000 & 1.000 & 1.000 & 1.000 & 0.942 & 1.000 & 0.992 \\
\hline Kehua Hengsheng & 0.962 & 0.856 & 0.860 & 0.886 & 0.891 & 1.000 & 0.957 & 0.916 \\
\hline
\end{tabular}

From the overall trend, the average pure technical efficiency of the PV installation industry in China reached 0.933 in 2017, indicating that the PV manufacturing industry was more efficient at using resources, but it had not yet reached the most effective state. It is worth noting that the pure technical efficiency of PV device industry also experienced a significant decline in 2011-2012, because of the shrinking oversea market. Due to market shrinkage, enterprises had reduced their spending on technological R\&D, exacerbating the decline in pure technical efficiency. In 2013-2017, the increasing domestic market demand had stimulated the recovery of pure technology, shortened the capital recovery period, and increased investment at the management and technology level, which subsequently promoted industrial efficiency. In addition, from the perspective of regulation, the Chinese government also increased its policy support to promote the recovery of the PV industry in China. In 2012, the "12th Five-Year Development Plan for Solar Photovoltaic Industry" was introduced to further enhance the strategic position of the PV industry and strengthen the strategic deployment of the industry; this policy stimulated investment in the PV industry in the following year, thereby improving industry efficiency.

3. Scale efficiency analysis 
Scale efficiency reflects the utilization of the existing scale. When the scale efficiency value is 1 , it indicates that there is a scale effect-that is, the current input and output scale is effective. When the input is constant, the output is maximized; when the output is constant, the input cost is the lowest. While the scale efficiency is less than 1 , it indicates that there is a diminishing scale effect, which needs to be optimized according to the specific situation.

It can be seen from Table 4 that the average scale efficiency of 25 representative PV installation enterprises in China during the whole sample period was 0.943 in 2017, showing an "S"-type change trend. In 2017, there were five enterprises with constant returns to scale (RTS), five enterprises with increasing RTS (irs), and 15 enterprises with decreasing RTS (drs), indicating that the PV installation industry in China was in an uneconomical state. Improving scale efficiency should therefore be a priority. The data indicated that the scale utilization of the PV installation industry in China was in an ineffective state; one of the possible explanations is that PV industry policy in China tends to promote the development of power generation, for example, the installed capacity of solar power generation is estimated to reach 110 million $\mathrm{kW}$ by 2020.A greatly promoted scale expansion of the PV device industry will follow. However, the level of industrial production capacity may not be simultaneously upgraded, causing idle waste at the enterprise scale, which causes overall scale inefficiency of the industry.

Table 4. Scale efficiency of PV installation enterprises, 2011-2017. (Source: Own elaboration.) (RTS: returns to scale.)

\begin{tabular}{|c|c|c|c|c|c|c|c|c|}
\hline Enterprise & 2011 & 2012 & 2013 & 2014 & 2015 & 2016 & 2017 & 2017 RTS \\
\hline CMC Magnetics & 0.995 & 0.995 & 0.903 & 0.954 & 0.978 & 0.964 & 0.929 & drs \\
\hline Jing Yuntong & 1.000 & 0.949 & 0.918 & 0.998 & 0.959 & 1.000 & 0.998 & irs \\
\hline Longji shares & 0.999 & 0.985 & 0.953 & 0.977 & 0.982 & 0.893 & 0.849 & drs \\
\hline Daquan New Energy & 1.000 & 0.525 & 0.590 & 1.000 & 1.000 & 0.969 & 1.000 & - \\
\hline Jinko Energy & 0.969 & 0.997 & 1.000 & 1.000 & 0.987 & 0.837 & 0.800 & drs \\
\hline Zhengtai Electric & 1.000 & 1.000 & 1.000 & 1.000 & 0.971 & 0.963 & 0.955 & drs \\
\hline Hairun PV & 0.903 & 0.935 & 0.863 & 0.931 & 0.956 & 0.939 & 0.992 & drs \\
\hline Jinjing Technology & 1.000 & 0.993 & 0.968 & 0.993 & 0.998 & 0.927 & 0.938 & drs \\
\hline Jinggong Technology & 1.000 & 0.847 & 0.671 & 0.926 & 0.825 & 0.941 & 0.979 & irs \\
\hline Yuhui Sunshine & 0.982 & 0.950 & 0.973 & 0.994 & 0.997 & 0.960 & 0.815 & irs \\
\hline Foster & 1.000 & 1.000 & 1.000 & 1.000 & 1.000 & 1.000 & 0.999 & irs \\
\hline Lin Yang Energy & 0.984 & 0.991 & 0.975 & 1.000 & 1.000 & 0.925 & 0.909 & drs \\
\hline $\begin{array}{c}\text { GCL System Integration } \\
\text { Technology }\end{array}$ & 0.982 & 0.920 & 0.413 & 1.000 & 1.000 & 1.000 & 1.000 & - \\
\hline Aikang Technology & 0.930 & 0.944 & 0.902 & 0.994 & 0.974 & 0.970 & 0.998 & drs \\
\hline CSG Holding & 0.997 & 0.966 & 0.925 & 0.986 & 0.969 & 0.888 & 0.867 & drs \\
\hline Zhongli Group & 1.000 & 1.000 & 1.000 & 0.909 & 0.880 & 0.884 & 0.902 & drs \\
\hline Kehua Hengsheng & 0.827 & 0.923 & 0.854 & 0.994 & 0.994 & 0.975 & 0.933 & drs \\
\hline TBEA & 0.915 & 0.764 & 0.830 & 0.875 & 0.861 & 0.853 & 0.898 & drs \\
\hline Annual Average & 0.945 & 0.868 & 0.837 & 0.937 & 0.906 & 0.942 & 0.943 & \\
\hline
\end{tabular}

\section{Malmquist Index Calculation}

The aforementioned analysis of the efficiency of PV devices is for a production technology at a certain time, but production is a long-term continuous process in which the technology itself is constantly changing. Therefore, this paper introduces the dynamic analysis of the PV device industry by introducing the Malmquist total factor index analysis method [65], which examines whether the technological progress or the technical efficiency change causes the total factor productivity to increase. Using DEAP v2.1 software [66], the overall technical efficiency change (EC), the technological progress 
change (TC) and the total factor productivity changes (TFP) of PV enterprises in China were calculated, and the results are shown in Table 5.

Table 5. Analysis of the total factor productivity of the PV installation industry in China, 2011-2017. (Source: Own elaboration.)

\begin{tabular}{cccccc}
\hline Year & $\begin{array}{c}\text { Overall Technical } \\
\text { Efficiency Change } \\
\text { (EC) }\end{array}$ & $\begin{array}{c}\text { Technological } \\
\text { Change (TC) }\end{array}$ & $\begin{array}{c}\text { Pure Technical } \\
\text { Efficiency } \\
\text { Change (Pech) }\end{array}$ & $\begin{array}{c}\text { Scale } \\
\text { Efficiency } \\
\text { Change (Sech) }\end{array}$ & $\begin{array}{c}\text { Total Factor } \\
\text { Productivity } \\
\text { Change (TFP) }\end{array}$ \\
\hline $2011-2012$ & 0.763 & 0.951 & 0.821 & 0.929 & 0.725 \\
$2012-2013$ & 1.076 & 0.952 & 0.993 & 1.084 & 1.025 \\
$2013-2014$ & 1.324 & 0.87 & 1.204 & 1.1 & 1.151 \\
$2014-2015$ & 0.978 & 0.987 & 1.069 & 0.915 & 0.966 \\
$2015-2016$ & 1.101 & 1.334 & 1.025 & 1.074 & 1.469 \\
$2016-2017$ & 0.974 & 1.268 & 0.976 & 0.998 & 1.235 \\
$\begin{array}{c}\text { Average annual } \\
\text { rate of change }\end{array}$ & 1.022 & 1.047 & 1.008 & 1.014 & 1.07 \\
\hline
\end{tabular}

1. Overall technical efficiency change

The average overall technical efficiency change index of the PV installation industry in China from 2011 to 2017 was 1.022, which showed a declining trend. This might be related to factors such as low utilization rate of fixed assets, redundant personnel, and large market risks in the PV installation industry in China. The change in overall efficiency was mainly due to changes in scale efficiency, especially in 2014-2015, when the pure technical efficiency change reached 1.069, showing an upward trend, while the change in scale efficiency change was only 0.915 , indicating the massive expansion of production capacity and the decline in demand. The production scale of the enterprise had not been fully utilized, and the industrial structure was not balanced, resulting in a decline in the overall technical efficiency, which is consistent with the conclusions of the aforementioned research.

2. Technological progress change

The average technological progress change index of the PV installation industry in China from 2011 to 2017 was 1.047, showing a slight downward trend. During this period, the pure technical efficiency changes were higher than the technological progress rate, and the technological change rate was less than 1 during the 2011-2014 period, indicating that the technological progress was generally ineffective. The upstream polycrystalline silicon sector of the PV industry is a technology-intensive industry with high technical requirements. The technological progress of the photovoltaic industry is mainly reflected in the technological progress change of polysilicon sector. Although the refining technology and equipment of polycrystalline silicon industry in China have been localized to a certain extent, the technological progress is slow.

3. Total factor productivity change

The index of total factor productivity was a comprehensive measure of efficiency changes. As shown in Table 5, the average total factor productivity change index of the PV installation industry in China in 2011-2017 was 1.07, which showed a downward trend. Especially in 2011-2012, there was a sharp decline, the change index being 0.725 . This was because the global installed capacity was approximately $28 \mathrm{GW}$ in 2011, while the module production capacity reached $63 \mathrm{GW}$. The expansion rate of production capacity was much higher than the growth rate of the PV market, resulting in an imbalance between supply and demand. At the same time, in 2012, the European government began to strictly control the incentive plan for the PV industry, which led to a shrinking market in Germany, Italy and France. The global PV industry had experienced a sharp decline in the economy. China's import and export trade of PV products was affected, resulting in decreased demand on inventory of PV installations. Moreover, during this period, the price of PV products continued to plummet. From the beginning of 2011 to December, the prices of polysilicon materials, wafers and battery chips 
had fallen by nearly $50 \%$. Some small and medium enterprises (SMEs) had already faced a struggle for survival, and all enterprises were finding it more difficult to survive. The business environment intensified, and performance dropped sharply. As a result, enterprises cut down various kinds of expenditure, leading to a reduction in efficiency across the entire industry.

During the period of 2015-2017, the total factor productivity index was greater than 1, showing an upward trend, which was the result of the combination of overall technical efficiency and technological progress efficiency; the effect of overall technological efficiency was more significant. During the period of 2014-2015, total factor productivity declined, eventually at 0.966 , which was caused by the decline in scale efficiency. Because of the repeated "anti-dumping and anti-subsidy survey" conducted by Europe and the United States, Chinese PV companies began to take new measures and strategies to cope with the situation. For example, Zhongli Group invested directly overseas in the construction of a 500 MV battery and module factory in Thailand, which was officially put into operation in 2015. Jinko Energy's component plant in Portugal was officially put into operation in January 2015. Other enterprises adopted overseas mergers and acquisitions (M\&A) and overseas original equipment manufacturers (OEMs) to avoid barriers imposed on PV products. These coping mechanisms show that PV installations gradually adjusted their strategy, which made enterprises pay less attention to the domestic market, reduced the scale of domestic market expansion and R\&D investment, and ultimately led to lower industrial efficiency. In the international market, the minimum import price agreement for PV products signed between the EU and China made the price of PV devices imported by China higher than the market price, which increased the product cost of the PV industry and reduced the average efficiency of the industry.

\section{Efficiency Measurement of the PV Power Generation Industry in China}

Since China's solar PV power generation started relatively later than in other countries, the unified statistical caliber data collection of the PV power generation industry in each province only started from 2011. In order to maintain data continuity and measurement accuracy, this paper selects 2011 as the earliest time node for measuring efficiency of power generation in the PV industry.

\subsection{Selection of Samples and Indicators}

Using 22 provinces and cities in China as research samples, according to the research results of past studies, power generation was selected as the output index. This is because power generation is the most important and accessible output of the power generation industry. For the selection of input indicators, this paper uses the number of employees in the power industry to measure labor input. In terms of measuring capital investment, the first task is to calculate the net value of fixed assets of the power generation industry by using the capital stock as the capital input standard [24]. The second is to use the installed capacity of power generation as a measure of capital investment. In our research, based on collected data, we did not find the net value of fixed assets in the PV power generation industry. Therefore, the cumulative installed capacity of the PV power generation industry was selected for measurement. PV power investments include technical facilities, land and other infrastructure costs [24], which can be considered as cost indicators.

The data of the Table 6 are from the China Electricity Statistical Yearbook [67], the statistical yearbooks of various provinces and cities in China, the China Energy Statistical Yearbook, and the Energy Bureau website (http://www.nea.gov.cn), thereby ensuring accuracy and accessibility. 
Table 6. Selection of efficiency measurement indicators for the PV power generation industry. (Source: Own elaboration.)

\begin{tabular}{cccc}
\hline & & Indicator Name & Unit \\
\hline \multirow{3}{*}{ Input indicator } & $\mathrm{X}_{1}$ & Cumulative installed capacity & Ten thousand $\mathrm{kW}$ \\
& $\mathrm{X}_{2}$ & Number of employees & Ten thousand people \\
& $\mathrm{X}_{3}$ & PV power investment & Billion yuan \\
Output indicator & $\mathrm{Y}$ & Power generation & Billion $\mathrm{kW} \cdot \mathrm{h}$ \\
\hline
\end{tabular}

Among them, the PV power generation data comes directly from the China Electricity Statistical Yearbook [68]. The cumulative installed capacity is derived from the amount of PV installations released by the Ministry of Industry and Information Technology over the years. The data on practitioners in the PV power generation industry are obtained through appropriate calculations. In the period of 2011-2017, China's solar PVs accounted for $0.01 \%, 0.07 \%, 0.16 \%, 0.42 \%, 0.69 \%, 1.1 \%$, and $1.82 \%$ of the total power generation, respectively. In view of the national conditions of China's energy development, the number of employees in the traditional energy power generation industry, such as thermal and hydropower, was found to be relatively stable. At the same time, the statistics on the number of people working in solar PV industry from China's 2011 Electricity Statistics Yearbook indicates that the number of employees in the PV industry accounts for $1 / 10$ of the power generation industry; we therefore assign the weights of 2012-2017 to 1/10, 2/10, 3/10, 4/10,5/10, and 6/10. The power generation investment data is derived from the China Electricity Yearbook, in which the data of each province and city are obtained through calculation.

\subsection{Analysis of DEA Efficiency Measurement Results}

As per the relevant data of the above-mentioned input/output indicators, the DEAP v2.1 software is also used to measure the efficiency of the PV power generation industry with the input-oriented BCC model and separately analyze the overall technical efficiency, the pure technical efficiency, and scale efficiency.

1. Overall technical efficiency analysis

According to Table 7, during the sample period, the overall technical efficiency (TE) of China's PV power generation was between 0.353 and 0.783 in each year, and the overall efficiency of PV power generation rose rapidly to a peak of 0.783 from 2015 to 2017 . When Wu et al. [39] studied the technical efficiency of the power generation industry in China, the technical efficiency of power generation in each province was divided into three levels: high efficiency, medium efficiency and low efficiency. The corresponding division criteria were $\mathrm{TE} \geq 0.9,0.6 \leq \mathrm{TE}<0.9$, $\mathrm{TE}<0.6$.

According to the situation of each province, in 2011-2017, the provinces and cities with a high efficiency of power generation greater than 0.9 were Qinghai and Tibet. Ningxia, Yunnan, and Shanghai were medium efficiency cities. The overall technical efficiency of most cities was low, including that of Hebei, Liaoning, Shanghai, Jiangsu, Zhejiang, Anhui, Fujian, Jiangxi, Shandong, Henan, Hubei, and Guangdong. It can be seen that in 2011-2017 that half of provinces and cities had a value lower than 0.6 , which was at a low efficiency level, and the power generation efficiency gap between provinces was large. This paper draws on this standard and believes that the PV power generation industry in China is at a medium level of efficiency. 
Table 7. Overall technical efficiency of the PV power generation industry in China, 2011-2017. (Source: Own elaboration.)

\begin{tabular}{ccccccccc}
\hline Area & $\mathbf{2 0 1 1}$ & $\mathbf{2 0 1 2}$ & $\mathbf{2 0 1 3}$ & $\mathbf{2 0 1 4}$ & $\mathbf{2 0 1 5}$ & $\mathbf{2 0 1 6}$ & $\mathbf{2 0 1 7}$ & Average Value \\
\hline Hebei & & & 0.335 & 0.339 & 0.482 & 0.850 & 0.850 & 0.571 \\
Shanxi & 0.030 & 0.871 & 1.000 & 0.519 & 0.482 & 0.908 & 0.908 & 0.674 \\
Inner Mongolia & 0.103 & 0.545 & 0.356 & 0.579 & 0.824 & 1.000 & 1.000 & 0.630 \\
Liaoning & & 0.063 & 0.487 & 0.631 & 0.619 & 0.813 & 0.813 & 0.571 \\
Shanghai & 0.952 & 0.927 & 1.000 & 0.616 & 0.303 & 0.043 & 0.043 & 0.555 \\
Jiangsu & 0.237 & 0.660 & 0.449 & 0.363 & 0.523 & 0.710 & 0.710 & 0.522 \\
Zhejiang & & 0.535 & 0.341 & 0.350 & 0.332 & 0.444 & 0.444 & 0.408 \\
Anhui & & 0.346 & 0.433 & 0.167 & 0.216 & 0.660 & 0.660 & 0.414 \\
Fujian & & 1.000 & 0.350 & 0.386 & 0.472 & 0.479 & 0.479 & 0.528 \\
Jiangxi & & 0.409 & 0.350 & 0.328 & 0.395 & 0.723 & 0.723 & 0.488 \\
Shandong & 0.762 & 0.702 & 0.620 & 0.416 & 0.362 & 0.603 & 0.603 & 0.581 \\
Henan & & & & 0.150 & 0.535 & 0.832 & 0.832 & 0.587 \\
Hubei & & 0.529 & 0.292 & 0.467 & 0.332 & 0.830 & 0.830 & 0.547 \\
Guangdong & 0.083 & 0.230 & 0.111 & 0.122 & 0.393 & 0.591 & 0.591 & 0.303 \\
Hainan & 0.182 & 1.000 & 0.404 & 0.819 & 0.560 & 0.844 & 0.844 & 0.665 \\
Yunnan & 1.000 & 0.662 & 0.623 & 0.688 & 0.696 & 0.986 & 0.986 & 0.806 \\
Tibet & 1.000 & 0.679 & 1.000 & 0.927 & 0.999 & 1.000 & 1.000 & 0.944 \\
Shaanxi & & 0.940 & 0.932 & 0.193 & 0.339 & 0.952 & 0.952 & 0.718 \\
Gansu & 0.519 & 0.553 & 0.487 & 0.518 & 0.689 & 0.986 & 0.986 & 0.677 \\
Qinghai & 1.000 & 1.000 & 1.000 & 1.000 & 1.000 & 1.000 & 0.998 & 1.000 \\
Ningxia & 0.887 & 1.000 & 0.751 & 1.000 & 0.848 & 0.963 & 0.963 & 0.916 \\
Xinjiang & & 0.637 & 0.203 & 0.895 & 1.000 & 1.000 & 1.000 & 0.789 \\
Annual average & 0.353 & 0.579 & 0.475 & 0.444 & 0.517 & 0.78 & 0.783 & - \\
\hline & & & & & & & &
\end{tabular}

During the sample period, the PV power generation efficiency in Qinghai Province could be termed adequate, indicating that its input and output combination in PV power generation was adequate. The is because Qinghai Province has abundant light resources, and the area was sparsely populated. Unutilized land resources are abundant-up to 100,000 square kilometers-and transportation is convenient. These superior comprehensive development conditions provide an excellent environment for the construction of PV power stations.

With China's PV installed capacity increasing and the scale of PV power generation expanding, the overall efficiency of the PV power generation industry continues to be low. The reason behind this is worthy of study. For a more in-depth analysis of the reasons behind this, similar to the previous approach, we continue to subdivide the overall technical efficiency into pure technical efficiency and scale efficiency.

2. Pure technical efficiency analysis

According to Table 8, during the sample period, the pure technical efficiency of the PV power generation industry fluctuated between 0.546 and 0.775 ; most of the time, it was between 0.5 and 0.6 , indicating that the PV power generation industry in China was purely technically inefficient.

Under these circumstances, the overall resource utilization of the industry was inefficient. This was because China's PV power generation started later than the world average; its power generation technology was backward, and its resource allocation capacity was insufficient.

Provinces and cities with high pure technical efficiency were Shanghai, Fujian, Hainan, Tibet, Qinghai, Ningxia. The provinces and cities with middle pure technical efficiency were Shanxi, Inner Mongolia, Liaoning, Shanghai, Fujian, Shandong, Henan, Hebei, and Gansu. The difference in pure technical efficiency between provinces and cities was large. PV power generation in Qinghai, Ningxia, Gansu, and other regions started relatively earlier; the industry is concentrated, the technology is relatively mature, and resources can be reasonably and effectively allocated. The high efficiency of Shanghai and Qinghai is due to the pulling of regional scientific research capabilities. Therefore, the PV power generation industry needs to improve the level of industrial technology and management. 
In particular, combined with the current situation of strong dependence on the import of PV equipment in China, enterprises need to strengthen technological innovation to further localize the imported equipment.

Table 8. Pure technical efficiency of the PV power generation industry in China, 2011-2015. (Source: Own elaboration.)

\begin{tabular}{ccccccccc}
\hline Area & $\mathbf{2 0 1 1}$ & $\mathbf{2 0 1 2}$ & $\mathbf{2 0 1 3}$ & $\mathbf{2 0 1 4}$ & $\mathbf{2 0 1 5}$ & $\mathbf{2 0 1 6}$ & $\mathbf{2 0 1 7}$ & Average Value \\
\hline Hebei & & & 0.339 & 0.346 & 0.482 & 0.851 & 0.850 & 0.574 \\
Shanxi & 0.524 & 0.881 & 1.000 & 0.540 & 0.482 & 0.909 & 0.908 & 0.749 \\
Inner Mongolia & 0.237 & 0.549 & 0.522 & 0.580 & 0.824 & 1.000 & 1.000 & 0.673 \\
Liaoning & & 0.443 & 0.487 & 1.000 & 0.973 & 0.857 & 0.813 & 0.762 \\
Shanghai & 1.000 & 1.000 & 1.000 & 1.000 & 0.782 & 1.000 & 1.000 & 0.969 \\
Jiangsu & 0.481 & 0.663 & 0.658 & 0.365 & 0.523 & 0.711 & 0.710 & 0.587 \\
Zhejiang & & 0.536 & 0.342 & 0.368 & 0.332 & 0.444 & 0.444 & 0.411 \\
Anhui & & 0.530 & 0.449 & 0.269 & 0.216 & 0.660 & 0.660 & 0.464 \\
Fujian & & 1.000 & 0.559 & 1.000 & 1.000 & 1.000 & 0.550 & 0.851 \\
Jiangxi & & 0.544 & 0.359 & 0.456 & 0.395 & 0.723 & 0.723 & 0.533 \\
Shandong & 1.000 & 0.715 & 0.650 & 0.447 & 0.362 & 0.603 & 0.603 & 0.626 \\
Henan & & & & 0.384 & 0.535 & 0.832 & 0.832 & 0.646 \\
Hubei & & 0.536 & 0.305 & 0.840 & 0.344 & 0.830 & 0.830 & 0.614 \\
Guangdong & 0.875 & 0.412 & 0.163 & 0.178 & 0.393 & 0.591 & 0.591 & 0.458 \\
Hainan & 1.000 & 1.000 & 0.944 & 0.899 & 0.702 & 1.000 & 1.000 & 0.935 \\
Yunnan & 1.000 & 0.667 & 0.623 & 0.721 & 0.697 & 0.987 & 0.986 & 0.812 \\
Tibet & 1.000 & 1.000 & 1.000 & 1.000 & 1.000 & 1.000 & 1.000 & 1.000 \\
Shaanxi & & 0.952 & 0.952 & 0.306 & 0.339 & 0.952 & 0.952 & 0.742 \\
Gansu & 0.898 & 0.554 & 0.541 & 0.538 & 0.690 & 0.986 & 0.986 & 0.742 \\
Qinghai & 1.000 & 1.000 & 1.000 & 1.000 & 1.000 & 1.000 & 0.999 & 1.000 \\
Ningxia & 1.000 & 1.000 & 0.809 & 1.000 & 0.851 & 0.963 & 0.963 & 0.941 \\
Xinjiang & & 0.640 & 0.217 & 0.936 & 1.000 & 1.000 & 1.000 & 0.799 \\
Annual average & 0.775 & 0.699 & 0.546 & 0.572 & 0.577 & 0.85 & 0.836 & - \\
\hline
\end{tabular}

3. Scale efficiency analysis

Based on the results of Table 9, the scale efficiency of the PV power generation industry in China showed an overall upward trend from 2011 to 2017. The average value of scale efficiency in 2017 reached 0.94, indicating that there was still room for improvement in the scale of the PV power generation industry in China. In 2017, most provinces and cities achieved the optimal scale except Shanghai, Fujian, Hainan and Yunnan.

The above results fully demonstrate that the PV power generation industry in China has the potential to expand and increase production, and that appropriately increasing the resources input can promote the further improvement of industrial efficiency. In 2014, China's PV power investment reached 15 billion, and it rose to 27 billion in 2017 , an increase of $80 \%$. It is estimated that by 2020 , the country will achieve a cumulative installed capacity of $100 \mathrm{GW}$, and the scale of PV power generation will continue to expand. From the perspective of the scale efficiency values of the provinces in 2017, the scale efficiency values of 18 provinces and cities in China were in the optimized condition. However, if the industrial scale continues to rise after reaching its optimum state, it will lead to redundancy of scale and even uneconomical scale. Therefore, China's excessive increase in PV installed capacity may reduce industrial efficiency. 
Table 9. Scale efficiency of the PV power generation industry, 2011-2015. (Source: Own elaboration.)

\begin{tabular}{ccccccccc}
\hline Area & $\mathbf{2 0 1 1}$ & $\mathbf{2 0 1 2}$ & $\mathbf{2 0 1 3}$ & $\mathbf{2 0 1 4}$ & $\mathbf{2 0 1 5}$ & $\mathbf{2 0 1 6}$ & $\mathbf{2 0 1 7}$ & $\mathbf{2 0 1 7}$ RTS \\
\hline Hebei & & & 0.991 & 0.980 & 0.998 & 0.9995 & 1.000 & - \\
Shanxi & 0.051 & 0.988 & 1.000 & 0.960 & 0.996 & 0.9996 & 1.000 & - \\
Inner Mongolia & 0.433 & 0.993 & 0.682 & 1.000 & 1.000 & 1.0000 & 1.000 & - \\
Liaoning & & 0.142 & 1.000 & 0.631 & 0.636 & 0.9479 & 1.000 & - \\
Shanghai & 0.952 & 0.927 & 1.000 & 0.616 & 0.388 & 0.0426 & 0.043 & irs \\
Jiangsu & 0.492 & 0.996 & 0.682 & 0.995 & 0.998 & 0.9997 & 1.000 & - \\
Zhejiang & & 0.999 & 0.994 & 0.950 & 0.996 & 1.0000 & 1.000 & - \\
Anhui & & 0.653 & 0.964 & 0.623 & 0.999 & 1.0000 & 1.000 & - \\
Fujian & & 1.000 & 0.626 & 0.386 & 0.472 & 0.4792 & 0.872 & irs \\
Jiangxi & & 0.751 & 0.974 & 0.720 & 0.996 & 1.0000 & 1.000 & - \\
Shandong & 0.762 & 0.981 & 0.954 & 0.931 & 0.995 & 1.0000 & 1.000 & - \\
Henan & & & & 0.390 & 0.999 & 1.0000 & 1.000 & - \\
Hubei & & 0.988 & 0.957 & 0.556 & 0.965 & 0.9999 & 1.000 & irs \\
Guangdong & 0.095 & 0.559 & 0.682 & 0.683 & 0.999 & 1.0000 & 1.000 & - \\
Hainan & 0.182 & 1.000 & 0.428 & 0.911 & 0.797 & 0.8438 & 0.844 & irs \\
Yunnan & 1.000 & 0.992 & 0.999 & 0.955 & 0.995 & 0.9991 & 0.999 & irs \\
Tibet & 1.000 & 0.679 & 1.000 & 0.927 & 0.998 & 1.0000 & 1.000 & - \\
Shaanxi & & 0.987 & 0.978 & 0.629 & 0.994 & 0.9999 & 1.000 & - \\
Gansu & 0.578 & 0.999 & 0.901 & 0.962 & 0.993 & 0.9995 & 1.000 & - \\
Qinghai & 1.000 & 1.000 & 1.000 & 1.000 & 1.000 & 1.0000 & 1.000 & dis \\
Ningxia & 0.887 & 1.000 & 0.928 & 1.000 & 0.996 & 0.9998 & 1.000 & irs \\
Xinjiang & & 0.995 & 0.935 & 0.956 & 1.000 & 1.0000 & 1.000 & - \\
average & 0.451 & 0.827 & 0.871 & 0.777 & 0.896 & 0.932 & 0.94 & \\
\hline
\end{tabular}

On the other hand, China's power grid infrastructure construction is completely out of line with power generation. Therefore, it is therefore difficult for the power grid to effectively transmit power to the power terminals, and the PV power generation capacity has not been effectively utilized, leading to serious light-emitting problems in the PV power generation industry, thereby hindering further improvement in industrial efficiency [69].

4. Efficiency comparison analysis

According to Figure 1, during the sample period, the average efficiency of the PV power generation industry in China was less than 1 , and it failed to reached the effective state, indicating that there is a great practical significance to studying China's PV power generation efficiency.

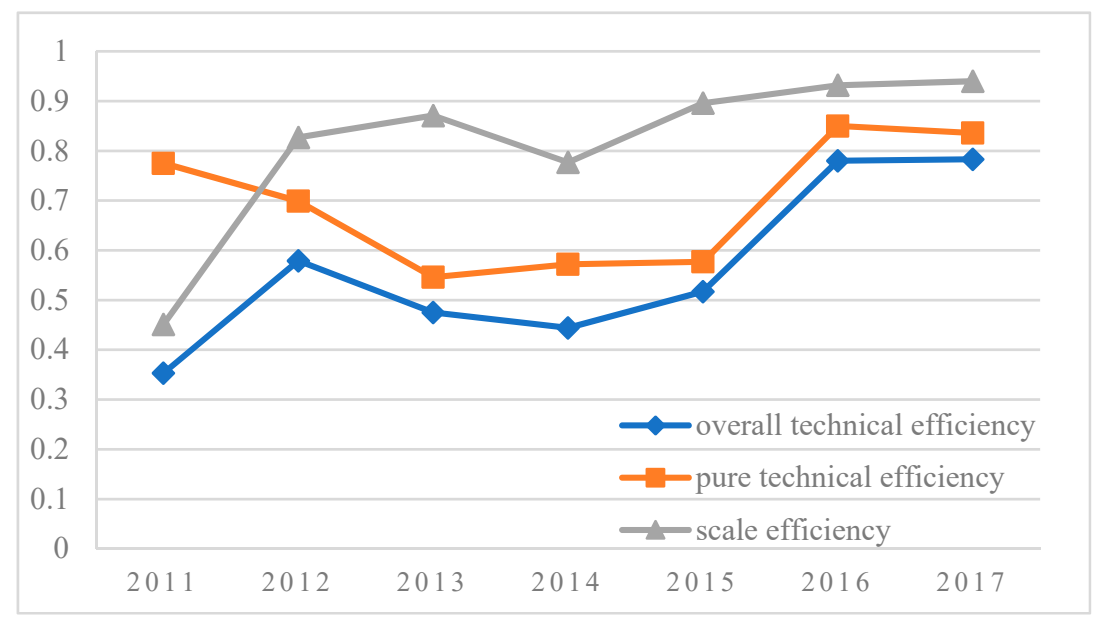

Figure 1. Analysis of the efficiency trend of the PV power generation industry in China, 2011-2017. (Source: Own elaboration.) 
Overall, the scale efficiency of the PV power generation industry was fluctuating upward, indicating that the PV power generation industry in China gradually improved in terms of resource allocation, management level, and technology utilization level. The trends of overall technical efficiency and scale efficiency were consistent. Pure technical efficiency was low and scale efficiency was always higher than overall technical efficiency. The scale efficiency of PV power generation had a great impact on the overall efficiency, indicating that the improvement of PV power generation efficiency in China is mainly dependent on expansion of scale efficiency, which is consistent with the development status of the PV industry in China.

In the period of 2011-2012, the changing trends of the overall technical efficiency and the scale efficiency were the same. The increase in scale efficiency was larger than the decrease in pure technical efficiency, which led to the improvement of the overall technical efficiency. This indicated that even though the pure technical efficiency of PV power industry was low, the expansion of the scale efficiency greatly promoted the improvement of the overall technical efficiency. From 2013 to 2015, the pure technical efficiency changed smoothly, and the overall efficiency of power generation in the PV industry declined. This indicated that the power generation industry had not fully utilized the existing production scale and there had been a large-scale waste. In 2015-2017, the overall technical efficiency had improved, which was the result of the combined influence of scale efficiency and pure technical efficiency; the impact of scale efficiency was, however, more significant. To sum up, the improvement of the overall efficiency of the PV power generation industry in China depended mainly on the benefits brought by the expansion of scale. Furthermore, the biggest factor contributing to the inefficiency of China was the low level of power generation technology.

\section{Analysis of Factors Affecting the Efficiency of the PV Industry}

According to the above analysis and calculation of the efficiency of the PV installations and power generation industry, the overall technical efficiency of the PV installation industry in China is at a medium level, and there is still room for improvement. The overall technical efficiency of the PV power generation industry is relatively low; the pure technical efficiency is especially at a considerably low level, which further indicates that there is a necessity to focus on efficiency improvement of the downstream power generation industry. Therefore, according to the characteristics of the PV industry, this section summarizes the influencing economic, technological, resource, market, policy and other factors of PV industry efficiency and uses the Tobit regression method to analyze the influencing factors.

\subsection{Analysis of Factors Affecting the Efficiency of PV Installations}

Using the limited Tobit model, the panel data of the representative 25 companies in the selected PV installation industry were analyzed from 2011 to 2017, and the driving factors for the development of the device industry were empirically studied. The specific model used is as follows

$$
\begin{gathered}
E E_{i t}=C+\alpha_{1} A T_{i t}+\alpha_{2} T P_{i t}+\alpha_{3} P E O_{i t}+\alpha_{4} S C_{i t}+\alpha_{5} \ln S P_{i t}+\alpha_{6} S U B_{i t}+\varepsilon_{i t} \\
i=1,2, \cdots \cdots, 25 ; t=1,2, \cdots \cdots, 7
\end{gathered}
$$

where $E E_{i t}$ represents the overall technical efficiency value of 25 PV installation enterprises in 2011-2017, using the overall technical efficiency results from DEA calculation in Section 2, and $C$ is a constant term. $A T$ represents asset turnover. TP stands for the proportion of technicians, $P E O$ represents per capita output value, $S C$ stands for cost of sales, $S P$ stands for production scale, $S U B$ stands for government subsidy amount. $\varepsilon$ is a random disturbance term, $i$ stands for enterprise, and $t$ represents the year.

According to the constructed model, EViews 9.0 software was applied to analyze the panel data of 25 companies in the PV device industry from 2011 to 2017. The results of the two models are almost the same (please see the Table 10). 
- The asset turnover rate passed the significance test in both models and has a positive correlation with industrial efficiency, indicating that the abundant capital has a significant role in promoting the efficiency of the PV device industry. The higher the abundance of enterprise funds, the more likely the enterprise is to invest money in production equipment upgrading, technology upgrading, production costs reduction, and efficiency level improvement. During the "12th Five-Year Plan" period, the PV device manufacturing industry in China gradually turned to refined development, in which the production cost of polycrystalline silicon links dropped to less than $\$ 10 / \mathrm{kg}$, the conversion rate of PV cells and modules reached over $15 \%$, and the localization rate of PV equipment reached $70 \%$ or more; the technology upgrade of the PV device industry was significantly accelerated [70]. Therefore, for PV installation enterprises, it is necessary to improve the use of inefficient and idle assets, speed up the recovery of sales funds, and thus improve the overall technical efficiency of the industry.

- The proportion of technicians was found to have a positive relationship with industrial efficiency. In Model 2, a $0.1 \%$ level of significance test was passed, indicating that the improvement of R\&D capability can promote the development of the device industry. An increase of 1 unit for technicians can increase the overall technical efficiency of the industry by approximately $40 \%$. Compared with accelerating capital turnover, focusing on changes in the structure of employees, the efficiency of the industry can be greatly improved.

- The per capita output value passed the significance test in both model 1 and model 2, showing a positive correlation with industrial efficiency, indicating that the increase in per capita output has a positive impact on the efficiency of the PV industry. Therefore, at the same input level, the higher the labor efficiency level, the higher the overall technical efficiency of the industry.

- The increasing in the ratio of sales cost to total cost had a positive impact on the efficiency of the PV industry, but it did not pass the significance test in both models. At this point, the increase in corporate sales expenses is related to the increase in corporate marketing investment, which has improved the efficiency of the industry. But this effect is not significant. The reason is that China's installation products are mainly targeted at overseas markets, while overseas political, economic, and trade tariffs, and other policy risks are relatively high. On the other hand, China's PV installed market is increasing during the 12th Five-Year Plan period. The increased market demand for PV products result in a large number of inefficient enterprises entering the market, exacerbating competition and lowering the profitability level of enterprises, which is not conducive to the sustainable development of the PV device industry.

- The empirical analysis showed that the production scale in model 1 had a negative impact on industrial efficiency, but the impact was not significant. In model 2, after the introduction of the secondary item of scale, the production scale of the primary item had a positive impact on the industrial efficiency, while the secondary item had a negative correlation with the industrial scale, which indicates that the relationship between production scale and industrial efficiency an open-down "U-shaped" relation. It shows that in the initial stage of industrial development, with the expansion of scale, the RTS increases, and the industrial efficiency shows an increasing trend. However, when the scale of the industry reaches a critical point, as the scale of the industry continues to expand, the RTS begins to decline. At the same time, the operating costs of enterprises increase, management becomes ineffective, and productivity turns idle, leading to an inefficiency in the scale of the industry.

- The government subsidy did not pass the significance test in both models, indicating that the incentive effect of the government subsidy on the development of the equipment industry is not good, and the government subsidy needs further improvement. China's PV subsidies are mainly financial subsidies, which are one-off subsidies. With a lack of post-regulation mechanisms, it is difficult to achieve effective subsidies, and the effect on sustainable development of industries is not obvious. Model 1 without the government subsidy squared item has a negative subsidy coefficient, while the model with squared items has a positive subsidy coefficient and a negative 
square factor coefficient. We think that because government subsidies may have an inverted U-shaped effect, the government subsidies at this time have not yet reached the inflection point and are still on the left side of the inverted U-shape.

Table 10. Analysis of the factors affecting the overall technical efficiency of PV installation industry. (Source: Own elaboration.)

\begin{tabular}{ccccccc}
\hline Variable Name & \multicolumn{3}{c}{ Model 1 } & \multicolumn{3}{c}{ Model 2 } \\
\cline { 2 - 7 } & $\begin{array}{c}\text { Coefficient } \\
\text { Value }\end{array}$ & $\begin{array}{c}\text { Standard } \\
\text { Deviation }\end{array}$ & Z Value & $\begin{array}{c}\text { Coefficient } \\
\text { Value }\end{array}$ & $\begin{array}{c}\text { Standard } \\
\text { Deviation }\end{array}$ & Z Value \\
\hline Asset turnover & 0.2196576 & 0.0561253 & $3.91^{* * *}$ & 0.2179421 & 0.0560076 & $3.89^{* * *}$ \\
Technical staff & 0.3962003 & 0.1291575 & $3.07^{* * *}$ & 0.4080893 & 0.1279905 & $3.19^{* * *}$ \\
$\begin{array}{c}\text { Per capita output value } \\
\text { Ratio of sales cost to total cost }\end{array}$ & 5.173824 & 1.227784 & $4.21^{* * *}$ & 5.099016 & 1.224846 & $4.16^{* * *}$ \\
$\quad \begin{array}{c}\text { Production scale } \\
\text { Scale square }\end{array}$ & -4.0303791 & 0.777543 & 0.36 & 0.0247968 & 0.0774734 & 0.32 \\
government subsidy & -0.0010566 & 0.000761 & 0.940843 & 0.000182 & 0.0001558 & 1.17 \\
$\quad$ Subsidy square & & & & $2.01 \times 10^{-7}$ & $1.43 \times 10^{-7}$ & -1.40 \\
\hline
\end{tabular}

Note: ${ }^{* * *}$ respectively, show that the $\mathrm{Z}$ test value passed the test at the significance level of $0.001,0.05$, and 0.1 .

\subsection{Analysis of Factors Affecting the Efficiency of the PV Power Generation Industry}

The restricted Tobit model was used to analyze the panel data of 22 provinces and cities in China from 2011 to 2017 and empirically study the driving factors of PV power industry development. The specific model used is as follows:

$$
\begin{gathered}
E F_{i t}=\beta+\alpha_{1} \ln G D P_{i t}+\alpha_{2} \ln E U_{i t}+\alpha_{3} P S_{i t}+\alpha_{4} E C_{i t}+\alpha_{5} P R_{i t}+\alpha_{6} G O V_{i t}+\varepsilon_{i t} \\
i=1,2, \cdots \cdots, 22 ; t=1,2, \cdots \cdots, 7
\end{gathered}
$$

where $E F_{i t}$ represents the overall technical efficiency value of the solar PV industry in 22 provinces and cities in 2011-2017 (please see the Table 11), using the aforementioned DEA to measure the overall technical efficiency value. EU represents PV equipment utilization, $P S$ represents actual solar energy development, $E C$ represents power consumption, $P R$ represents power generation, and GOV represents carbon dioxide emissions. $\varepsilon$ is a random disturbance item, $i$ stands for business, and $t$ stands for the year.

Table 11. Analysis of the factors affecting the efficiency of PV power generation, 2011-2017. (Source: Own elaboration.)

\begin{tabular}{ccccc}
\hline Variable & Coefficient & Standard Deviation & Z Statistic & $p$ Value \\
\hline $\ln (\mathrm{GDP})$ & -0.211334 & 0.1978433 & -1.07 & 0.288 \\
Equipment utilization & 1.093636 & 0.0754971 & 14.49 & $0.000^{* * *}$ \\
Solar development utilization & 0.0039358 & 0.0074361 & 0.53 & 0.598 \\
Electricity consumption & 0.000016 & 0.0000533 & 0.30 & 0.765 \\
$\ln ($ power generation scale) & 0.0451229 & 0.0192829 & 2.34 & $0.021^{* *}$ \\
$\ln \left(\mathrm{CO}_{2}\right)$ & -0.1460661 & 0.0570799 & -2.56 & $0.012^{* *}$ \\
\hline
\end{tabular}

Note: ${ }^{* * *}$ and ${ }^{* *}$, respectively, show that the $\mathrm{Z}$ test value passed the test at the significance level of $0.001,0.05$.

According to the constructed model, EViews 9.0 software was used to empirically analyze the influencing factors.

By performing a Tobit estimation on the above influencing factors, the following can be ascertained:

The impact of PV equipment utilization level on power generation efficiency is positive, and the impact is significant, indicating that the impact of PV power generation equipment utilization on industrial efficiency is very crucial. Compared to other variables, equipment utilization has the 
greatest impact on PV power generation efficiency. Therefore, how to improve the utilization rate of PV equipment has become a key point in the PV power generation industry. On the one hand, China's PV power generation technology has been upgraded, and lighting resources can be fully utilized, which have led to an increase in industrial efficiency. On the other hand, during the "12th Five-Year Plan" period in China, the National Development and Reform Commission of China issued the "Notice on Improving the On-grid Price Policy for Solar Photovoltaic Power Generation" to further standardize the PV power generation market, which promoted investment in PV power generation projects; thus, the installed capacity of PV power generation equipment increased rapidly. The limitation of capacity constraints on the efficiency of PV power generation was weakened.

The scale of PV power generation had a positive impact on power generation efficiency, and passed the significance test, indicating that the larger the scale of PV power generation, the higher the efficiency of the PV industry. The expansion of industrial scale is conducive to the emergence of scale effect, thereby reducing overall production costs, helping to increase production, and thus promoting industrial efficiency. During the 12th Five-Year Plan period, China's PV installed capacity increased rapidly, and the industry accelerated its expansion. Thus, the cost of PV power generation decreased by approximately $70 \%$, which was close to 1 yuan $/ \mathrm{kWh}$. At the same time, the amount of PV power generation has increased rapidly, and the PV industry has ushered in a stage of large-scale development, forming economies of scale. On the other hand, China's PV power stations are concentrated in Inner Mongolia, Gansu, Qinghai, Ningxia, Xinjiang, and other regions. The high industrial concentration brings economic spillovers to the power generation industry, resulting in a " $1+1>2$ " effect, which has improved the overall technical efficiency of the industry.

The impact of $\mathrm{CO}_{2}$ emissions on power generation efficiency was found to have a negative impact and pass the significance test. This means that China not only can reduce carbon emissions but also can promote the development of the PV industry through environmental regulations. But the implementation needs to be further strengthened, because if the supervision is not strong, the companies would not invest in low carbon technology. Strengthening the environmental regulation of carbon emissions will make enterprises to pay more attention to the environmental impact in terms of energy consumption, and then increase the practical application of PV power generation. This will promote the development of the PV industry from another aspect.

The theoretical reserves of solar energy and the efficiency of PV power generation shows a positive correlation, and the richer the light resources, the higher the PV power generation efficiency. It should be noted that the PV power generation industry belongs to the resource endowment industry, and power generation efficiency is closely related to the abundance of light resources. However, the PV power industry in China is at an initial stage of development, and the level of power generation technology is not very advanced. As a result, simple input of resources and expansion of industrial scale have a certain role in promoting industrial development. Therefore, at present, the PV power industry still needs to increase installed capacity, further develop available lighting resources, improve power generation, and ultimately enhance the level of industrial efficiency.

There is a positive correlation between electricity consumption and PV power generation efficiency. In general, market demand is an important factor in promoting industrial development. The greater the demand for electricity, the greater the pulling effect on electricity production, and the further alleviation of regional power surplus. However, the impact was not significant, and the possible reason for the contradiction is that China's demand for PV electricity is strong in inter-provincial areas and economically developed regions such as the eastern coastal areas, but PV power plants are concentrated in underdeveloped areas in the northwest. Moreover, the power transmission system has not been optimized, which makes it difficult for the power generation industry to effectively output power generation, causing serious light-abandoning problems, which is not conducive to the efficiency improvement of the PV power generation industry.

The GDP was found to have a negative impact on the efficiency of solar PV power generation, but it also did not pass the significance test. This is because the rich regions of light resources are 
mostly in economically less developed areas in China, such as Xinjiang, Inner Mongolia, Gansu, and Qinghai. These regions have the most abundant light resources, but due to some reasons such as low population density and bad geographical environment, the economy is underdeveloped compared with the eastern region of China.

\section{Conclusions and Suggestion}

In this paper, the DEA method is used to measure the efficiency of the PV device industry and the power generation industry and analyze the factors affecting the efficiency of different industrial sectors. It was found that in the PV device sector, the industrial efficiency is at a medium level, and it is necessary to strengthen standardization and awareness at the industrial scale. The power generation industry as a whole is at a low level of efficiency, with the low technical level having a particularly negative impact on industrial efficiency. Therefore, we need to put forward effective policy recommendations for improving the efficiency of the PV industry at both the enterprise and government levels.

At the enterprise level, it is urgent to develop and upgrade the entire industrial chain in the direction of pursuing high quality, high efficiency, low subsidy, sustainability, and marketization as well as becoming environmentally friendly. Firstly, the PV industry chain is facing the problem of improving scale efficiency. PV enterprises should optimize the scale of the industry and reduce the cost of each link by extending the entire industry chain to achieve higher returns. Secondly, enterprises should pay close attention to market development, enhance the market service level, establish and improve the collaborative channel closely connected with the terminal market, and quickly identify changes in the market with a more sensitive touch. The third is to pay attention to the cultivation of professional talents, improving the innovative ability of enterprises, breaking through technical restrictions, and transforming the traditional extensive and labor-intensive development nodes into key and high value-added links in the industrial chain.

At the government level, the main goal is to create a more harmonious environment for industrial development. The specific practices can be divided into three parts. The first is to provide R\&D subsidies to promote the transformation and upgrading of the PV industry. The second is to standardize the market access mechanism of the PV industry and form barriers to entry. The third is to speed up the construction of infrastructure, promote the development of power transmission and distribution links, optimize the power grid development plan, and gradually open up the east-west and north-south power transmission channels in China, more effectively transmitting PV power supply to the demand side, so as to improve the efficiency of the PV power generation industry.

This study only selects the main links in the PV industry chain for efficiency analysis, such as polysilicon, batteries, module manufacturing, and PV power generation, which has not completely covered the entire industry chain. In future studies, we will consider PV cell recovery, PV wind power complementation, and other links in the whole industrial chain to improve the effectiveness of the research.

Author Contributions: The authors contributed equally to the paper and author names are in alphabetical order. The detail work content of co-authors are as follows: H.C.: Writing-original draft, Validation; L.L.: Methodology, Formal analysis, Software; J.T.: Writing—review \& editing; Q.W.: Writing—original draft; L.W.: Data Collection, Writing-review \& editing; J.X.: Conceptualization, Validation, Data Resources.

Funding: The work was supported by the Chinese National Funding of Social Sciences (Grant No. 15ZDB161) and Humanities and Social Sciences Foundation of Ministry of Education in China (Grant No. 18YJA790042).

Acknowledgments: The authors contributed equally to the paper and author names are in alphabetical order. The authors thank the editor, and the anonymous reviewers for their valuable suggestions that have significantly improved this study. The work was supported by the Chinese National Funding of Social Sciences (Grant No. 15ZDB161) and Humanities and Social Sciences Foundation of Ministry of Education in China (Grant No. 18YJA790042).

Conflicts of Interest: The authors declare no competing interest. All authors state that no financial and personal relationships with other people or organizations that could inappropriately influence (bias) their work. 


\section{References}

1. De Castro, C.; Mediavilla, M.; Miguel, L.J.; Frechoso, F. Global solar electric potential: A review of their technical and sustainable limits. Renew. Sustain. Energy Rev. 2013, 28, 824-835. [CrossRef]

2. Ghaffour, N.; Bundschuh, J.; Mahmoudi, H.; Goosen, M.F. Renewable energy-driven desalination technologies: A comprehensive review on challenges and potential applications of integrated systems. Desalination 2015, 356, 94-114. [CrossRef]

3. Website of National Energy Administration. Related Energy Situation. 2017. Available online: http: //www.nea.gov.cn/2018-01/24/c_136920159.htm (accessed on 10 May 2019). (In Chinese)

4. Yu, L.; Li, Y.P.; Huang, G.H. Planning municipal-scale mixed energy system for stimulating renewable energy under multiple uncertainties-The City of Qingdao in Shandong Province, China. Energy 2019, 166, 1120-1133. [CrossRef]

5. Renewable Energy Policy Network for the 21st Century (REN21); Renewables 2017 Global Status Report; REN21 Secretariat: Paris, France, 2017; ISBN 978-3-9818107-6-9.

6. Shuai, J.; Chen, C.F.; Cheng, J.; Leng, Z.; Wang, Z. Are China's solar PV products competitive in the context of the Belt and Road Initiative? Energy policy 2018, 120, 559-568. [CrossRef]

7. $\mathrm{Xu}, \mathrm{Y} . ; \mathrm{Li}, \mathrm{J} . ; \mathrm{Tan}, \mathrm{Q}$.; Peters, A.L.; Yang, C. Global status of recycling waste solar panels: A review. Waste Manag. 2018, 75, 450-458. [CrossRef] [PubMed]

8. Tsai, S.B. Using the DEMATEL model to explore the job satisfaction of research and development professionals in china's photovoltaic cell industry. Renew. Sustain. Energy Rev. 2018, 81, 62-68. [CrossRef]

9. Xue, J. Photovoltaic agriculture-New opportunity for photovoltaic applications in China. Renew. Sustain. Energy Rev. 2017, 73, 1-9. [CrossRef]

10. Sun, B.; Yu, Y.; Qin, C. Should China focus on the distributed development of wind and solar photovoltaic power generation? A comparative study. Appl. Energy 2017, 185, 421-439. [CrossRef]

11. Liu, D.; Hang, X. The politics of curtailment: multi-level governance and solar photovoltaic power generation in China. Environ. Politics 2018, 27, 852-871. [CrossRef]

12. Su, X.; Masoum, M.A.; Wolfs, P.J. Optimal PV Inverter Reactive Power Control and Real Power Curtailment to Improve Performance of Unbalanced Four-Wire LV Distribution Networks. IEEE Trans. Sustain. Energy 2014, 5, 967-977. [CrossRef]

13. Liu, P.; Chu, P. Wind power and photovoltaic power: How to improve the accommodation capability of renewable electricity generation in China. Int. J. Energy Res. 2018, 42, 2320-2343. [CrossRef]

14. Tang, N.; Zhang, Y.; Niu, Y.; Du, X. Solar energy curtailment in China: Status quo, reasons and solutions. Renew. Sustain. Energy Rev. 2018, 97, 509-528. [CrossRef]

15. Maudos, J.; De Guevara, J.F. Factors explaining the interest margin in the banking sectors of the European Union. J. Bank. Financ. 2004, 28, 2259-2281. [CrossRef]

16. Casu, B.; Molyneux, P. A Comparative Study of Efficiency in European Banking. Appl. Econ. 2003, 35, 1865-1876. [CrossRef]

17. Sickles, R.C. Panel estimators and the identification of firm-specific efficiency levels in parametric, semiparametric and nonparametric settings. J. Econom. 2005, 126, 305-334. [CrossRef]

18. Reddy, K.S.; Nirmala, V. Profit Efficiency and Its Determinants: Evidence from Indian Commercial Banks. J. Transnatl. Manag. 2013, 18, 125-163. [CrossRef]

19. Olatubi, W.O.; Dismukes, D.E. A data envelopment analysis of the levels and determinants of coal-fired electric power generation performance. Util. Policy 2000, 9, 47-59. [CrossRef]

20. Granderson, G.; Prior, D. Environmental externalities and regulation constrained cost productivity growth in the US electric utility industry. J. Product. Anal. 2013, 39, 243-257. [CrossRef]

21. Von Hirschhausen, C.; Cullmann, A.; Kappeler, A. Efficiency analysis of German electricity distribution utilities-Non-parametric and parametric tests. Appl. Econ. 2006, 38, 2553-2566. [CrossRef]

22. Liu, W.; Lin, B. Analysis of energy efficiency and its influencing factors in China's transport sector. J. Clean. Prod. 2018, 170, 674-682. [CrossRef]

23. Campisi, D.; Gitto, S.; Morea, D. An Evaluation of Energy and Economic Efficiency in Residential Buildings Sector: A Multi-Criteria Analisys on an Italian Case Study. Int. J. Energy Econ. Policy 2018, 8, 185-196.

24. Petrović, M.; Bojković, N.; Stamenković, M. A DEA-based tool for tracking best practice exemplars: The case of telecommunications in EBRD countries. Econ. Ann. 2018, 218, 105-127. [CrossRef] 
25. Li, H.Z.; Kopsakangas-Savolainen, M.; Xiao, X.Z.; Tian, Z.Z.; Yang, X.Y.; Wang, J.L. Cost Efficiency of Electric Grid Utilities in China: A comparison of estimates from SFA-MLE, SFA-Bayes and StoNED-CNLS. Energy Econ. 2016, 55, 272-283. [CrossRef]

26. Li, S.L. Research on calculation of new energy's power generation efficiency and analysis on its driving factors. Resour. Sci. 2016, 38, 321-332.

27. Zhao, H.; Zhao, H.; Guo, S. Operational Efficiency of Chinese Provincial Electricity Grid Enterprises: An Evaluation Employing a Three-Stage Data Envelopment Analysis (DEA) Model. Sustainability 2018, 10, 3168. [CrossRef]

28. Zheng, B.; Prince, P.E. Purchasing Efficiency Measurement of Selected Chinese PV Panels Using Data Envelopment Analysis (DEA). Undergrad. Rev. 2015, 11, 148-155.

29. Zou, H.; Du, H.; Ren, J.; Sovacool, B.K.; Zhang, Y.; Mao, G. Market dynamics, innovation, and transition in China's solar photovoltaic (PV) industry: A critical review. Renew. Sustain. Energy Rev. 2017, 69, 197-206. [CrossRef]

30. Campisi, D.; Morea, D.; Farinelli, E. Economic sustainability of ground mounted photovoltaic systems: An Italian case study. Int. J. Energy Sect. Manag. 2015, 9, 156-175. [CrossRef]

31. Branker, K.; Pathak, M.J.M.; Pearce, J.M. A review of solar photovoltaic levelized cost of electricity. Renew. Sustain. Energy Rev. 2011, 15, 4470-4482. [CrossRef]

32. Kong, Y.; Wu, J. Analysis of the Operational Efficiency of Chinese Listed Coal Enterprises Based on Super Efficiency DEA and Tobit Models. Shanghai Manag. Sci. 2014, 36, 49-54.

33. Ding, M.; Xu, Z.; Wang, W.; Wang, X.; Song, Y.; Chen, D. A review on China's large-scale PV integration: Progress, challenges and recommendations. Renew. Sustain. Energy Rev. 2016, 53, 639-652. [CrossRef]

34. Wei, M.; Patadia, S.; Kammen, D.M. Putting renewables and energy efficiency to work: How many jobs can the clean energy industry generate in the US. Energy Policy 2010, 38, 919-931. [CrossRef]

35. Van den Heuvel, S.T.; Van den Bergh, J.C. Multilevel assessment of diversity, innovation and selection in the solar photovoltaic industry. Struct. Chang. Econ. Dyn. 2009, 20, 50-60. [CrossRef]

36. Tanţău, A.D.; Regneală, H.; Coraş, E.L. Layout design as a risk driver for energy efficiency of photovoltaic power systems. Int. J. Manag. Sci. Inf. Technol. 2014, 11, 124-151.

37. Zhang, L.; Wang, J.; Wen, H.; Fu, Z.; Li, X. Operating performance, industry agglomeration and its spatial characteristics of Chinese photovoltaic industry. Renew. Sustain. Energy Rev. 2016, 65, 373-386. [CrossRef]

38. Gollop, F.M.; Roberts, M.J. Environmental regulations and productivity growth: The case of fossil-fueled electric power generation. J. Political Econ. 1983, 91, 654-674. [CrossRef]

39. BAI, X.J.; Song, Y. Environment regulation, technology innovation and efficiency improvement of Chinese thermal power industry. China Ind. Econ. 2009, 8, 68-77.

40. Wu, L.; Sun, K.; Shi, Z. Research on cost technical efficiency of coal power generation enterprises in China under environmental regulation. China Popul. Resour. Environ. 2018, 8, 31-38.

41. Chen, S.; Liu, X.; Chang, Q. Empirical analysis on the factors affecting the photovoltaic industry based on Tobit model. Sci. Technol. Manag. Res. 2017, 37, 144-148.

42. Wang, Y.; Li, Y.; Kong, F.Y. Energy efficiency analysis of Beijing using the DEA-Tobit two stage method. Adv. Mater. Res. 2012, 608-609, 1210-1214. [CrossRef]

43. Zhang, S.S.; Wang, X.; Zhang, X. The Application of DEA/AHP in Evaluating Comprehensive Benefits of Heating Equipments. In Proceedings of the 2010 International Conference on E-Business and E-Government, Guangzhou, China, 7-9 May 2010.

44. Medina-Borja, A.; Triantis, K. Modeling social services performance: A four-stage DEA approach to evaluate fundraising efficiency, capacity building, service quality, and effectiveness in the nonprofit sector. Ann. Oper. Res. 2014, 221, 285-307. [CrossRef]

45. Yu, G.; Huang, Q.; Zhao, X.J.; Wang, W.S. Efficiency Evaluation and Optimization of Green Mining for Coal Enterprises Based on DEA. Appl. Mech. Mater. 2013, 295, 2864-2868. [CrossRef]

46. Ganji, S.S.; Rassafi, A.A. DEA Malmquist productivity index based on a double-frontier slacks-based model: Iranian road safety assessment. Eur. Transp. Res. Rev. 2019, 11. [CrossRef]

47. Chiu, Y.H.; Huang, C.W.; Ma, C.M. Assessment of China transit and economic efficiencies in a modified value-chains DEA model. Eur. J. Oper. Res. 2011, 209, 95-103. [CrossRef]

48. Krivonozhko, V.E.; Førsund, F.R.; Rozhnov, A.V.; Lychev, A.V. Measurement of returns to scale using a non-radial DEA model. Dokl. Math. 2012, 85, 144-148. [CrossRef] 
49. Jha, D.K.; Shrestha, R. Measuring Efficiency of Hydropower Plants in Nepal Using Data Envelopment Analysis. IEEE Trans. Power Syst. 2006, 21, 1502-1511. [CrossRef]

50. Zervopoulos, P.; Palaskas, T. Applying quality-driven, efficiency-adjusted DEA (QE-DEA) in the pursuit of high-efficiency-high-quality service units: An input-oriented approach. IMA J. Manag. Math. 2011, 22, 401-417. [CrossRef]

51. Branda, M. Reformulations of input-output oriented DEA tests with diversification. Oper. Res. Lett. 2013, 41, 516-520. [CrossRef]

52. Titko, J.; Jureviciene, D. DEA Application at Cross-country Benchmarking: Latvian vs Lithuanian Banking Sector. Procedia Soc. Behav. Sci. 2014, 110, 1124-1135. [CrossRef]

53. Fernandez-Lopez, X.L. Impact of Logistics on Technical Efficiency of World Production (2007-2012). Netw. Spat. Econ. 2015, 26, 1-15.

54. Ruggiero, J. Measuring technical efficiency. Eur. J. Oper. Res. 2000, 121, 138-150. [CrossRef]

55. Li, Z.; Crook, J.; Andreeva, G. Dynamic prediction of financial distress using Malmquist DEA. Expert Syst. Appl. 2017, 80, 94-106. [CrossRef]

56. Yu, Y.; Shi, Q. Two-stage DEA model with additional input in the second stage and part of intermediate products as final output. Expert Syst. Appl. 2014, 41, 6570-6574. [CrossRef]

57. Imanirad, R.; Cook, W.D.; Zhu, J. Partial Input to Output Impacts in DEA: Production Considerations and Resource Sharing Among Business Sub-Units. Nav. Res. Logist. 2013, 60, 355-380. [CrossRef]

58. Charnes, A.; Cooper, W.W.; Rhodes, E. Measuring the efficiency of decision making units. Eur. J. Oper. Res. 1978, 2, 429-444. [CrossRef]

59. Staiger, R.W.; Wolak, F. Measuring Industry Specific Protection: Anti-dumping in the United States. Brookings Papers on Economic Activity. Microeconomics 1994, 1, 51-118.

60. Krupp, C.M.; Pollard, P.S. Market responses to anti-dumping laws: Some evidence from the U.S. Chemical industry. Can. J. Econ. 1996, 29, 199-227. [CrossRef]

61. Konings, J.; Vandenbussche, H. Anti-dumping protection and markups of domestic firms: Evidence from firm level data. J. Int. Econ. 2005, 65, 151-165. [CrossRef]

62. Bown, C.P.; Crowley, M.A. Trade deflection and trade depression. J. Int. Econ. 2007, 72, 176-201. [CrossRef]

63. Wang, H.; Wang, J.; Feng, Z. The economic effects of anti-dumping and anti-subsidy policies among China, the U.S. and the EU: The photovoltaic industry. Singap. Econ. Rev. 2018, 63, 513-534. [CrossRef]

64. Zuo, X. China's PV industry suffered 'winter: Causes and Counter measures. Econ. Forum 2012, 10, 111-113.

65. Rácz, V.J.; Vestergaard, N. Productivity and efficiency measurement of the Danish centralized biogas power sector. Renew. Energy 2016, 92, 397-404. [CrossRef]

66. Li, N.; Jiang, Y.; Yu, Z.; Shang, L. Analysis of agriculture total-factor energy efficiency in China based on DEA and malmquist indices. Energy Procedia 2017, 142, 2397-2402. [CrossRef]

67. China Electric Power Yearbook. Available online: http://tongji.cnki.net/kns55/navi/HomePage.aspx?id= N2018060073\&name=YZGDL\&floor=1 (accessed on 10 May 2019).

68. Yan, Y.; Qian, Y.; Sharif, H.; Tipper, D. A survey on smart grid communication infrastructures: Motivations, requirements and challenges. IEEE Commun. Surv. Tutor. 2012, 15, 5-20. [CrossRef]

69. Barros, C.P.; Chen, Z.; Wanke, P. Efficiency in Chinese seaports: 2002-2012. Marit. Econ. Logist. 2016, 18, 295-316. [CrossRef]

70. Yuan, X.; Zuo, J. Transition to low carbon energy policies in China-from the Five-Year Plan perspective. Energy Policy 2011, 39, 3855-3859. [CrossRef]

(C) 2019 by the authors. Licensee MDPI, Basel, Switzerland. This article is an open access article distributed under the terms and conditions of the Creative Commons Attribution (CC BY) license (http://creativecommons.org/licenses/by/4.0/). 